ISSN 2078-6441. Вісник Львівського університету. Серія географічна. 2013. Випуск 41. С. 358-366. Visnyk of the Lviv University. Series Geography. 2013. Issue 41. P. 358-366.

504:546.16:61 (477.74)

\author{
лентин ригуб \\ деський н ціон льний університет імені . . ечников , \\ пров. мп нський, 2, 65058, м. дес, кр їн
}

изн чено геогр фічні особливості вмісту фтору в природних компонент $\mathrm{x}$ дещини. иявлено вплив фтору н 3 хворюв ння н селення деської обл. і деси н деякі стом тологічні 3 хворюв ння з лежно від його вмісту в питних вод х.

лючові слов : фтор, природні компоненти, питні води, деськ обл., стом тологічні 3 хворюв ння, медико-геогр фічн оцінк .

т н здоров'я н селення є в жливим пок зником з г льного бл гополуччя суспільств, т кож тонким індик тором усіх соці льних т екологічних нег р здів у держ ві. івень 3 хворюв ності н селення 3 лежить від 6 г тьох чинників і визн чений економічними т соці льними умов ми, екологічною ситу цією, рівнем медичної допомоги тощо.

ьогодні фтор - один з н йпоширеніших з бруднюв чів у повітрі, грунті, природних вод х, продукт х х рчув ння. ін т кож н лежить до ктивних тмосферних і водних мігр нтів.

н слідок зрост ння з бруднення н вколишнього середовищ фтором зн чно збільшилось і н дходження його в орг нізм людей. г льновідомо, що нест ч його, як і н длишок, у продукт х х рчув ння і питній воді виклик $є$ тяжкі з хворюв ння ендемічний флюороз зубів і кісток, остеосклероз, нервові хвороби, стом тологічні з хворюв ння, порушення обміну речовин в орг нізмі, порушення роботи нирок, прискорене ст ріння орг нізму людини тощо. одноч с є 6 г то пит нь, які потребують спецільних досліджень н суч сному рівні. собливу ув гу приверт є низк пит нь щодо виявлення осередків ендемічних з хворюв нь і прогнозув ння територій екологічного ризику.

ослідження, метою яких є медико-геогр фічне р йонув ння великих регіонів з обліком природних, соці льно-економічних і медико-с ніт рних умов, особливо кту льне і необхідне. нтегр льні оцінюв льні х р ктеристики в сфері медико-геогр фічного p йонув ння великих регіонів м ють щор з більше з стосув ння. кремі пр ці т кого н пряму, вид ні ост нніми рок ми, присвячені медико-геогр фічному к ртогр фув нню території кр їни. ише невелик кількість пр ць присвячен проблем м медикоекологічних досліджень в окремих регіон х. собливий інтерес для вивчення можуть ст новити територі льні одиниці, н прикл д, деськ обл.

осі опубліков но низку пр ць, присвячених проблемі медико-геогр фічного вивчення чинників середовищ, демогр фічних і епідеміологічних процесів у регіоні. дним з н йв жливіших чинників, що визн ч є індивіду льне і популяційне здоров'я, $є$ вод [3-5]. он д $75 \%$ н селення кр їни спожив є воду з поверхневих джерел водо-

(C) ригуб ., 2013 
пост ч ння, які з кл сом якості є “помірно з брудненими” і “з брудненими”. огляду н це знижується трив лість життя, зрост є смертність, збільшується кількість хворих, зменшується кількість н селення кр їни. тже, якість питної води є однією з головних екологічних проблем не тільки кр їни, й всього людств . сесвітня орг ніз ція охорони здоров'я ( ) приділяє особливе зн чення вивченню хвороб, які пов'яз ні $з$ використ нням бо вжив нням неякісної води.

б’єктом н шого дослідження є фтор у вз ємопов'яз ній системі природне середовище-людин ; предметом - особливості поширення фтору в природних компонент х $\mathrm{i}$ питних вод х деської обл. т міст дес, його вплив н 3 хворюв ність н селення деякими стом тологічними хвороб ми.

ет дослідження - виявлення впливу якості питної води н ст н здоров'я н селення дещини.

ля визн чення зон ризику н підст ві вивчення особливостей сольового скл ду питної води деської обл. методом к ртогр фув ння пост влено й вирішено т кі з д чі: про н лізов но з кономірності поширення фтору в природних компонент х; виявлено суч сні джерел з бруднення природних, у тому числі й питних вод; вивчено якісний скл д питної води деської обл.; досліджено вміст у ній іонів фтору т їхню причетність до рівня ур ження зубів мешк нців різних р йонів обл сті к рієсом т флюорозом; оцінено фізіологічну декв тність питної води, яку використовує н селення обл сті т м. деси; проведено к ртогр фув ння деської обл. $з$ умов ми водопост ч ння (у тому числі з вмістом фтору) з виділенням р йонів підвищеного ризику.

ля вирішення пост влених з вд нь використ но вл сні дослідження вмісту фтору в природних компонент х (у тому числі питних вод $\mathrm{x}$ ) дещини, т кож фондові м тері ли нституту стом тології к демії медичних н ук кр їни шодо стом тологічного ст тусун селення дещини.

осліджув ли: вміст фтору в грунт х, підземних, поверхневих (у тому числі питних) т стічних вод $\mathrm{x}$ дещини; причетність вмісту фтору в питних вод $\mathrm{x}$ до рівня ур ження н селення н к рієс і флюороз зубів.

міст фтору в природних компонент х визн ч ли потенціометричним методом із 3 стосув нням фтор-селективного електрод м рки F-IV.

ході оцінюв ння впливу мінер льних компонентів питної води н ст н здоров'я н селення використовув ли інтегр льні пок зники якості питної води.

ок зник якості питної води, що відобр ж є її фізіологічну декв тність, розр ховув ли н підст ві р нжув ння н йбільш зн чимих компонентів сухого $з$ лишку: 3 г льної мінер ліз ції, вмісту к тіонів к льцію, м гнію, хлорид- і сульф т-іонів. к критерії фізіологічної декв тності води взято рекомендов ні $\quad$ (1993) рівні [2] нжув ння виконув ли з схемою (т бл. 1).

тупінь ризику оцінюв ли н підст ві зіст влення інтегр льного пок зник якості води з критеріями, н веденими в т бл. 2.

нтегр льний пок зник якості води (фізіологічної декв тності) обчислюв ли 3 формулою

$$
P_{J i}=\sum_{i=1}^{n} / N,
$$

де $P_{j i}$ - інтегр льний пок зник якості води; $j, i-$ зн чення окремих пок зників якості води, б ли; $n$ - кількість пок зників (6). 
и усвідомлюємо, що т кий методичний підхід м є певну умовність, одн к він д $є$ змогу впорядкув ти велику кількість пок зників з їхніми різними зн ченнями й оцінюв ти їх з одн кових рівнозн чних позицій.

блиця 1

цінюв льн шк л якісного скл ду питної води

\begin{tabular}{|c|c|c|c|}
\hline \multirow{2}{*}{ ок зники } & \multicolumn{3}{|c|}{ ли } \\
\cline { 2 - 4 } & 1 & 2 & 3 \\
\hline $\begin{array}{c}\text { г льн } \\
\text { мінер ліз - } \\
\text { ція, мг/л }\end{array}$ & $500-1000$ & $1000-1500$ & $>1500$ \\
\hline $\begin{array}{c}\text { г льн } \\
\text { твердість, } \\
\text { мг екв/л }\end{array}$ & $<7$ & $7-10$ & $>10$ \\
\hline $\begin{array}{c}\text { лориди, } \\
\text { мг/л }\end{array}$ & $<100$ & $100-250$ & $>250$ \\
\hline $\begin{array}{c}\text { ульф ти, } \\
\text { мг/л }\end{array}$ & $<200$ & $200-400$ & $>400$ \\
\hline $\begin{array}{c}\text { льцій, } \\
\text { мг/л }\end{array}$ & $<100$ & $100-200$ & $>200$ \\
\hline гній, мг/л & $<15$ & $15-50$ & $>50$ \\
\hline тор, мг/л & $<0,5$ & $0,5-1,5$ & $>1,5$ \\
\hline
\end{tabular}

ивчення якісного скл ду питної води деської обл. д ло змогу викон ти к ртогр фув ння обл сті з виділенням р йонів підвищеного ризику з умов ми водопост ч ння, у тому числі з вмістом фтору, т виявити з лежність стом тологічних з хворюв нь від вмісту фтору в питній воді.

міст фтору в природних компонент $\mathrm{x}$ дещини колив ється в широких меж х. собливості н копичення фтору в грунт х зумовлені регіон льними і 3 г льними геогр фічними з кономірностями. 'ясов но, шо вміст фтору в грунт х колив ється в т ких меж х: в лового - 131,0-670,0 мг/кг, водорозчинного - 0,70-6,73 мг/кг. міст фтору в грунт х

ридун йської провінції зн чно вищий, ніж у

блиця 2

ритерії інтегр льної оцінки мінер льного скл ду води

\begin{tabular}{|c|c|}
\hline н чення & р ктеристик якості \\
\hline$<1,3$ & ізіологічно допустим \\
\hline $1,31-1,7$ & $\begin{array}{c}\text { езн чний ризик для } \\
\text { здоров'я }\end{array}$ \\
\hline$>1,7$ & исокий ризик для здоров'я \\
\hline
\end{tabular}
грунт х зово- ричорноморської, що спричинено відмінностями гр нулометричного скл ду, вмістом гумусу, к рбон тів, легкорозчинних солей т меліор тивного ст ну грунтів. иявлено т кож з кономірне збільшення вмісту фтору у верхніх горизонт х грунтів від елюві льних до тр нселюві льних (схили) і кумулятивних (з пл ви річок, днищ $б$ лок) л ндш фтів від 1,0 до 7,0 мг/кг, що свідчить про його високу мігр ційну ктивність. ертик льн диференці ція чорноземів південних і лесової товщі з вмістом фтору визн чен , н с мперед, особливостями їхнього гр нулометричного скл ду т х р ктером розподілу легкорозчинних солей і к рбон тів к льцію. ксим льні зн чення в лового вмісту фтору в ілюві льно-к рбон тних горизонт х сяг ють 1000 мг/кг, водорозчинного - 30 мг/кг. міст фтору в рослин х з лежить від його вмісту в грунт х: збільшення вмісту водорозчинного фтору в грунт х спричиняе підвищення його кількості в рослин х і грунтових вод х [9]. 
явність техногенно з бруднених фтором грунтів деси пов'яз не з н явністю викидів промислових підприємств т втотр нспорту. ехногенне з бруднення виявляється в н копиченні в лових і особливо водорозчинних форм фтору. ксим льний ступінь з бруднення грунтів міст в 50 р зів вищий порівняно з фоновим. ступінь з бруднення грунтів водорозчинним фтором зн чно вплив є і х р ктер сільськогоспод рського використ ння.

дним з головних джерел н дходження фтору в орг нізм людини є природні води. імічний скл д природних вод формується під впливом б г тьох природних чинників (клім т, хімічний скл д водовмісних порід, тектонік , водообіг т ін.), що зумовлює їхню гідрохімічну зон льність - горизонт льну (площину) і вертик льну (глибину). н чно вплив є н скл д води, перев жно нег тивно, і техногенн діяльність людини [11].

одні ресурси деської обл. скл д ються з 3 п сів підземних т поверхневих вод.

п си поверхневих вод н території обл сті розподілені нерівномірно. йбільше 3 безпеченим є південний з хід, який тяжіє до річок ністер т ун й, північн т центр льн ч стини території м ють обмежені з п си води. безпеченість потреби підземними вод ми питної якості з г лом по обл сті ст новить $28 \%$. йже н $72 \%$ питне водопост ч ння обл сті відбув ється з поверхневих джерел. тже, якість води у поверхневих водних об'єкт х є виріш льним чинником с ніт рного т епідеміологічного бл гополуччя н селення деської обл. [8].

інер ліз ція, хімічний скл д т, зокрем, вміст фтору в підземних і грунтовопідгрунтових вод х території досліджень формуються головно з р хунок тр нзиту їх 3 кр їнського крист лічного щит і одільської височини. ідземні води м ють підвищені пок зники вмісту фтору (0,21-2,91 мг/л), які в окремих вип дк х перевищують гр ничнодопустимі концентр ції. оди, приурочені до водоносних горизонтів лесової форм ції, м ють нижчі пок зники вмісту фтору (0,16-0,80 мг/л), більші зн чення вмісту фтору простежено у водоносних горизонт х, які приурочені до нижньочетвертинних і верхньопліоценових відкл дів (1,6-2,09 мг/л) [9].

сновними джерел ми н дходження фтору в поверхневі води $є$ фторовмісні мінер льні добрив, хімічні меліор нти, стічні води. н ліз літер турних джерел стосовно вмісту фтору в поверхневих вод х досліджув ної території з свідчив, що т кі д ні $€$ поодинокими. дослідженнями - бович, вміст фтору у вод $\mathrm{x}$ ністр $\epsilon$ в меж $\mathrm{x}$ 0,09-0,21 мг/л, івденного угу - 0,17-0,30 мг/л, ун ю-0,10-0,25 мг/л) [1]. н шими визн ченнями, вміст фтору в поверхневих вод $\mathrm{x}$ дещини колив ються в широких меж $\mathrm{x}-$ від 0,17 до 1,22 мг/л. езульт ти визн чення вмісту фтору в поверхневих вод $\mathrm{x}$ досліджув ної території з ост нне десятиріччя з свідчили тенденцію щодо його підвищення у вод х ун ю, ністр , івденного угу т м лих річок дністер'я [9].

риродні води виявилися т кож зручним місцем для скид ння промислових і комун льних стоків. міст фтору в стічних вод $\mathrm{x}$ підприємств деси $є$ в меж $\mathrm{x}$ 0,11-1,35 мг/л, у б г тьох вип дк х перевищуючи гр ничнодопустимі концентр ції [10].

ході н лізу якості питної води (див. т бл. 3), використовуючи р нжув ння н йзн чиміших компонентів питної води інтегр льно з шістьм пок зник ми (з г льн мінер ліз ція, з г льн твердість, к льцій, м гній, хлориди і сульф ти), виявили, що до територій з високим ступенем ризику для здоров'я н селення 3 умов ми водопост ч ння н леж ть: ерезівський, олгр дський, ілгород- ністровський, омінтернівський, икол ївський, оздільнянський, т рбун рський р йони, в яких пок зник інтегр льної оцінки мінер льного скл ду води зн чно перевищив 1,7 б л . йон ми підвищеного ризику з інтегр льним індексом якості 1,67 б л є рцизський, еликомих й- 
лівський, зм їльський, отовський, $\mathrm{p}$ сноокнянський, вр нський, $\mathrm{p}$ тський. о територій з незн чним ризиком безпеки питних вод н леж ть н ньївський, в нівський, одимський, відіопольський, рутинський, рунзівський і иряєвський р йони. тільки чотири р йони обл сті м ють фізіологічно допустиму з сольовим скл дом питну воду: енійський, ілійський, іляєвський і лтський.

блиця 3

інер льний скл д питних вод дещини

\begin{tabular}{|l|c|c|c|c|c|c|c|}
\hline \multicolumn{1}{|c|}{ йон } & $\begin{array}{c}\text { інер - } \\
\text { ліз ція, } \\
\text { мг/л }\end{array}$ & $\begin{array}{c}\text { г льн } \\
\text { твердість, } \\
\text { мг екв/л }\end{array}$ & $\mathrm{Ca}, \mathrm{Mг} / л$ & $\mathrm{Mg}$, мг/л & $\begin{array}{c}\text { лориди, } \\
\text { мг/л }\end{array}$ & $\begin{array}{c}\text { ульф - } \\
\text { ти, мг/л }\end{array}$ & $\begin{array}{c}\text { тор, } \\
\text { мг/л }\end{array}$ \\
\hline н ньївський & 643 & 7,6 & 50,4 & 53,5 & 31,6 & 135,7 & 0,48 \\
\hline рцизький & 1564 & 2,4 & 8,9 & 13,2 & 156,8 & 309,3 & 1,92 \\
\hline лтський & 724 & 3,7 & 61,2 & 49,8 & 26,4 & 164,3 & 0,45 \\
\hline іляївський & 568 & 5,2 & 60,0 & 25,4 & 50,0 & 110,0 & 0,21 \\
\hline ерезовський & 1013 & 12,1 & 64,5 & 104,0 & 286,8 & 248,1 & 0,44 \\
\hline олгр дський & 1191 & 17,1 & 167,1 & 97,0 & 278,1 & 353,1 & 0,51 \\
\hline $\begin{array}{l}\text { ілгород- } \\
\text { ністровський }\end{array}$ & 1680 & 5,4 & 38,8 & 41,8 & 608,8 & 222,5 & 0,73 \\
\hline еликомих йлівський & 689 & 10,0 & 94,0 & 64,0 & 66,0 & 274,0 & 0,42 \\
\hline в нівський & 809 & 4,4 & 31,7 & 33,2 & 128,0 & 211,8 & 0,65 \\
\hline зм їльський & 606 & 10,0 & 65,3 & 35,2 & 286,8 & 155,9 & 0,65 \\
\hline ілійський & 378 & 4,2 & 58,5 & 19,6 & 30,3 & 51,4 & 0,28 \\
\hline одимський & 728 & 7,7 & 84,3 & 45,3 & 92,5 & 357,9 & 0,28 \\
\hline омінтернівський & 1290 & 6,5 & 39,3 & 54,7 & 430,0 & 343,4 & 0,47 \\
\hline отовський & 771 & 9,2 & 69,4 & 68,9 & 54,6 & 204,2 & 0,58 \\
\hline р сноокняський & 647 & 8,8 & 69,5 & 64,1 & 42,0 & 226,84 & 0,65 \\
\hline юб шівський & 609 & 5,6 & 42,0 & 42,6 & 119,0 & 68,0 & 0,60 \\
\hline икол ївський & 859 & 11 & 103,0 & 104,6 & 128,0 & 326,6 & 0,60 \\
\hline відіопольський & 836 & 3,8 & 24,0 & 31,8 & 176,9 & 139,6 & 0,64 \\
\hline оздільнянський & 508 & 12,3 & 140,0 & 64,0 & 253,0 & 293,0 & 0,32 \\
\hline енійський & 995 & 6,2 & 78,0 & 27,4 & 87,3 & 84,3 & 0,32 \\
\hline вр нський & 945 & 8,9 & 85,7 & 52,7 & 157,8 & 166,0 & 0,23 \\
\hline р тський & 1682 & 1,3 & 8,5 & 10,6 & 234,0 & 335,9 & 1,15 \\
\hline рутинський & 813 & 3,7 & 29,2 & 27,7 & 120,5 & 115,7 & 1,84 \\
\hline т рбун рський & 1641 & 2,2 & 15,3 & 17,8 & 451,0 & 373,9 & 0,53 \\
\hline рундзівський & 631 & 9,2 & 56,5 & 76,8 & 53,5 & 165,4 & 0,53 \\
\hline иряївський & 497 & 7,6 & 40,0 & 67,4 & 75,6 & 76,8 & 0,53 \\
\hline дес & $374-478$ & $4,2-5,4$ & $40-51$ & $16-48$ & $45-50$ & $75-120$ & $0,12-0,23$ \\
\hline & $<1000$ & $<7$ & $<7$ & & 350 & 500 & $0,5-1,5$ \\
\hline
\end{tabular}

сновним джерелом водопост ч ння деси $є$ р. ністер, в яку кожен рік потр пляє

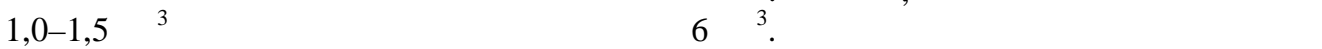
скл ду дністерської води, хоч і $є$ декв тними для біологічних потреб орг нізму, все ж т ки $з$ ост нні 20 років зн чно змінилися. більшилися з г льн мінер ліз ція, вміст хлоридів, інших хімічних елементів.

огляду н глоб льне з бруднення поверхневих вод центр лізов не водопост ч ння міст щор з більше орієнтується н підземні води. дним 3 льтерн тивних джерел водопост ч ння н селення в десі є використ ння вод ртезі нських свердловин верх- 
ньос рм тського водоносного горизонту, який з ляг є н глибині 108-130 м від поверхні. Г льн кількість свердловин, обл дн них у верхньос рм тському горизонті, 186, прид тних для використ ння н селенням - 134 .

підст ві н лізу д них різних вторів можн стверджув ти, що хімічний скл д води бюветних комплексів відповід є норм м н ником якості вод є фізіологічно допустимою. од центр лізов ного водопост ч ння міст м є незн чний ризик для здоров'я.

міст фтору в усіх бюветних комплекс х м лий і колив ється в меж х 0,09-0,23 мг/л, шо є дуже низьким (який зумовлює широком сшт бні ур ження к рієсом).

к відомо, різні концентр ції фтору нег тивно вплив ють н орг нізм людини, спричиняючи різні з хворюв ння, особливо стом тологічні. сновні стом тологічні 3 хворюв ння н леж ть до хвороб, у виникненні т поширенні яких соці льні т екологічні чинники відігр ють зн чну роль. евною мірою їх можн вв ж ти хвороб ми цивіліз ції, тому що головними причин ми, які супроводжують поширення т розвиток цих 3 хворюв нь, є порушення структури т якості х рчув ння (підвищення ступеня обробки іжі, вжив ння вуглеводів, зменшення жув льного і фізичного н в нт ження тощо) $[1,3-5,7]$.

ослідження вмісту фтору в питних вод х дещини н ведені в т бл. 3 . зн чної в рі бельності рівнів фтору в питних вод х $(0,12-1,92$ мг/л) визн чено зони його підвищеного вмісту (вище ), що охоплюють рцизький (1,92 мг/л; в окремих проб х вміст фтору досяг в 5 мг/л), рутинський (1,84 мг/л; в окремих проб х - до 3,8 мг/л) і

т рбун рський (1,48 мг/л) р йони. птим льний вміст фтору визн чений тільки в одному р йоні обл сті - $\mathrm{p}$ тському (1,15 мг/л). ередній вміст фтору $(0,44-0,73$ мг/л) 3 фіксов но в н ньївському, лтському, ерезівському, ілгород- ністровському, олгр дському, еликомих йлівському, в нівському, зм їльському, омінтернівському, отовському, p сноокнянському, юб шівському, икол ївському, відіопольському, рунзівському т иряївському р йон х. о зони з низьким вмістом фтору $(0,28-0,32$ мг/л) н леж ть ілійський, одимський і енійський р йони. йнижчий вміст фтору (0,12-0,23 мг/л) м ють питні води оздільнянського, іляївського,

вр нського р йонів [11].

изн чення з хворюв ності дитячого н селення обл сті н деякі стом тологічні п тології з свідчило, що є певні з кономірності поширення к рієсу т флюорозу зубів 3 лежно від вмісту фтору в питній воді.

1. високого вмісту фтору в питній воді (вище ) $80 \%$ н селення хворіє н т ке стом тологічне з хворюв ння, як ендемічний флюороз зубів. рім того, підвищені концентр ції мікроелемент спричиняють т кі з хворюв ння: ендемічний флюороз кісток, порушення роботи селезінки, гіпертрофія щитоподібної з лози (збільшення в декільк р зів).

2. р зі підвищеного вмісту фтору 3-5\% н селення цих р йонів хворіє н флюороз першого т другого ступеня. хворюв ння н к рієс близьке до мінім льного.

3. низьких концентр цій фтору в питній воді з хворюв ність н селення н к рієс зубів у три-чотири р зи більш, ніж у р зі оптим льної концентр ції фтору. дітей простежується з тримк окостеніння і дефекти мінер ліз ції кісток. лямистість ем лі зубів першого ступеня може бути в 1-3\% н селення [2].

ег тивн ситу ція з фіксов н й н території деси. к 3 зн чено вище, н селення міст для спожив ння використовує воду р. ністер і підземні води з бюветних комплексів. міст фтору в цих вод х дуже низький і колив ється від 0,15 до 0,24 мг/л. 
огляду н це серед н селення н йпоширенішим стом тологічним 3 хворюв нням $є$ к рієс зубів. чені нституту стом тології провели дослідження з визн чення рівня стом тологічних з хворюв нь у дітей різного віку деси. к тегорії до 7 років к рієс виявлений у $81,5 \%$ обстежув них дітей, у групі 12 років поширеність к рієсу - 68,8 \%, у к тегорії 15 років - 80,86\%.

оряд з великим відсотком з хворюв ності н к рієс з реєстров но і великий відсоток $з$ хворюв ності н флюороз. прикл д, у к тегорії до 7 років флюороз виявлений у 78,58 \% обстежув них дітей, у к тегорії до 12 років - у 64,79, у к тегорії до 15 років $75,92 \%$ [2]. е пов'яз но з виділенням н території міст промислових зон, де особливо висок з брудненість викид ми підприємств, тр нспорту тощо. о т ких зон н леж ть вулиці орноморського оз цтв (р йон ересипу), олодимир инниченк , імічн, територія рипортового з воду т ін. міст фтору в природних компонент х цих територій може в десятки р зів перевищув ти фоновий вміст, відповідно,

підст ві проведених досліджень можн зробити висновок, що як низький, т к і високий вміст фтору в орг нізмі людини призводить до тяжких з хворюв нь. територіях з різним умістом фторидів у питній воді фтор-профіл ктик к рієсу виклик $\epsilon$ з непокоєння через з грозу розвитку флюорозу. е з хворюв ння тр пляється не тільки $з$ високого, й з оптим льного вмісту фторидів у питній воді.

в ж ють, що оптим льний (т кий, що не виклик є ні флюорозу, ні к рієсу) уміст фтору у воді ст новить 1,2 мг/л, низький (той, що спричиняє к рієс) - 0,45, дуже низький (який спричиняє широком сшт бні ур ження к рієсом) - 0,25 мг/л [6]. днією 3 можливих причин стом тологічних хвороб, н віть 3 оптим льного вмісту фтору в питній воді, може бути поєдн н його дія з іншими елемент ми.

тже, фтор н лежить до мікроелементів, які виявляють всебічну дію, і для норм льної життєдіяльності орг нізмів необхідний у чітко лімітов них кількостях. міст фтору у воді - один з критеріїв, що визн ч є прид тність води до використ ння в господ рстві і, особливо, у питному водопост ч нні н селення.

підст ві вивчення відмінностей окремих х р ктеристик мінер льного скл ду від норм тивів, розр хунку інтегр льного індексу якості питних вод виділено р йони підвищеного ризику з умов ми водопост ч ння: ерезовський, олгр дський, ілгородністровський, омінтернівський, икол ївський, т рбун рський. рцизський, еликомих йлівський, зм їльський, отовський, р сноокнянський, вр нський і p тський. н ньївський, в нівський, одимський, відіопольський, рутинський, рунзівський і иряєвський р йони н леж ть до територій помірного ризику. тільки чотири р йони обл сті м ють фізіологічно допустиму з сольовим скл дом питну воду: енійський, ілійський, іляєвський і лтський.

иявлено кореляційну з лежність між пок зник ми вмісту фтору в природних вод х деської обл. і пок зник ми поширеності стом тологічних з хворюв нь серед н селення обл сті.

фіксов но високий рівень з хворюв ності н флюороз у рутинському, рцизському і т рбун рському р йон х, де вміст фтору в питних вод х перевищує , т високу з хворюв ність н к рієс у оздільнянському і іляєвському р йон х, які н леж ть до зони з низьким вмістом фтору (0,21 мг/л).

изн чено інтегр льний пок зник якості питної води м. деси (центр лізов не водопост ч ння т води бюветних комплексів) 3 шістьм основними компонент ми і фтором. од бюветних комплексів 3 інтегр льним пок зником якості є фізіологічно допустимою. од центр лізов ного водопост ч ння міст м є незн чний ризик для 
здоров'я. міст фтору в питних вод х міст дуже низький, що може призвести до високої з хворюв ності н селення н к рієс.

иявлено, що для н селення міст х р ктерні високі пок зники з хворюв ння як н к piєc, т к і флюороз, що пов'яз но з виділенням промислових р йонів зі зн чним нтропогенним н в нт женням, у тому числі й сполук ми фтору.

оцільно систем тично проводити моніторинг питних вод як м. деси т к і обл сті з г лом для з побіг ння з хворюв ності н селення, зокрем н стом тологічні хвороби.

\section{СПИСОК ВИКОРИСТАНОЇ ЛІТЕРАТУРИ}

1. бович . . тор в стом тологии и гигиене / . . бович, . . вруцкий. 3 нь, 1965. $-512 \mathrm{c}$.

2. віт про н уково-дослідну роботу нституту стом тології кр їни. 041.01. “ ивчення епідеміології основних стом тологічних з хворюв нь у дітей деської обл сті у вз ємозв'язку з біогеохімічними ф ктор ми оточуючого середовищ ”. дес , 2001.-341 с.

3. обенко . . собенности солевого сост в воды подземных и открытых водоисточников десской обл сти в связи со здоровьем н селения / . . обенко, . . дворный, . . иков, . . уденко, . . орохт // існик морської медицини. - 1998. - № 3. - . 97-98.

4. $\quad$ удрый . . влиянии минер льного сост в питьевой воды н здоровье человек (обзор) / . . . удрый // игиен и с нит рия. - 1999. - № 1. - . 15-18.

5. ейко . . едико-геологічний н ліз ст ну довкілля як інструмент оцінки т контролю здоров'я н селення / . . ейко, . удько, . . моляр. - дес : кор, 2001. - 350 c.

6. уденко . . плив вз ємодії люмінію і фтору н 3 хворюв ння к рієсом мешк нців івнічної уковини / . . уденко, . . ом'юк, . . ербець, . . ілянович // кологія т ноосферологія. - 2005. - . 16. - № 3-4. - . 243-248.

7. мирнов . . остояние имунной системы при эндемическом флюорозе / . . мирнов, . . еньг , . . ороз, . . етленко // ммунология. - 1999. № 6. - . .52-54.

8. т н довкілля деської обл сті. егіон льн доповідь про ст н н вколишнього природного середовищ в деській обл сті у 2010 році // ричорноморський екол. бюл. - 2011. - № 3 (41). - . 7-100.

9. ригуб . . тор у чорнозем х південного з ходу кр їни: моногр фія / . . ригуб, . . озняк. - ьвів : ім. . p нк , 2008. - 148 с.

10. ригуб . . тор у природних т стічних вод х івденного ходу кр їни / . . ригуб, . . гн т // існик дес. ун-ту. ер. геогр. т геол. н уки. -2011 . .16. - ип. $1 .-.76-85$.

11. ригуб . . міст фтору в питних вод $\mathrm{x}$ дещини т його вплив н 3 хворюв ність н селення к рієсом і флюорозом зубів / . . ригуб // існик дес. ун-ту. ер. геогр. т геол. н уки. $-2012 .-$. 17. - ип. 2 (15). - .71-79.

m ття: н дійшл до ред кцї̈ 27.08.2012

доопр иьов н 12.12.2012

прийнят до друку 20.02.2013 


\title{
MEDICAL-GEOGRAPHICAL ASSESSMENT OF FLUORIDE IN NATURAL COMPONENTS OF ODESSA REGION
}

\author{
Valentina Trigub \\ Ilya Mechnikov National University of Odessa, \\ Shampanskyi Lane, 2, UA-65058, Odesa, Ukraine
}

Geographic features of fluoride in groundwater and surface (including drinking) waters of the Odessa region and Odessa city are established. Found some correlation between dental diseases of population of Odessa region and contents of the fluoride in drinking waters.

Key words: fluorine, natural ingredients, drinking waters, dental diseases, Odessa region, medicalgeographical assessment.

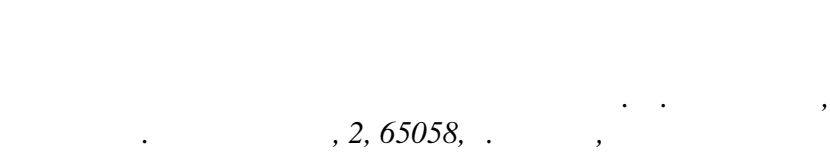

ст новлено геогр фические особенности содерж ния фтор в природных компонент х десщины. ыявлено влияние фтор н з болев емость н селения десской обл. и г. десс некоторыми стом тологическими болезнями в $з$ висимости от его содерж ния в питьевых вод х.

лючевые слов : фтор, природные компоненты, питьевые воды, десск я обл., стом тологические болезни, медико-геогр фическ я оценк . 